\title{
PENERAPAN ARSITEKTUR EKSPRESIONISME PADA PERANCANGAN GEDUNG PUSAT KREATIVITAS DI KOTA KENDARI
}

\author{
Ferdiansyah ${ }^{1}$, Ilham ${ }^{2}$, Dian Puteri Nurbaity ${ }^{3^{*}}$ \\ 1,3 Program Studi Arsitektur, Fakultas Teknik, Universitas Muhammadiyah Kendari \\ 2 Jurusan Arsitektur, Fakultas Teknik, Universitas Halu Oleo \\ *dianputeri.nurbaity@umkendari.ac.id
}

\author{
INFORMASI ARTIKEL \\ Diterima Redaksi: \\ 11 Agustus 2021 \\ Revisi Akhir: \\ 07 September 2021 \\ Diterbitkan: \\ Cetak: \\ 19 September 2021 \\ Online \\ 19 September 2021
}

\section{Abstract}

The creative economy industry is currently starting to develop rapidly in some cities in Indonesia, including Kendari City. Although relatively young, the development of the creative economy in Kendari City is supported by the increasing enthusiasm of young people in this industry. Therefore, to support the interests and talents of the people of Kendari City, especially young people, this study aims to create a place in the form of a Creativity Center Building with the theme of Expressionism. This theme is considered in accordance with the existing conditions in this city which can describe the expression of building users which is reflected in the appearance and interior of the building. This research uses qualitative descriptive and quantitative methods. Based on the analysis of location and site determination, this building is planned to be built in Kadia District with a total area of $\pm 4.34 \mathrm{Ha}$. The design of the facade /in this building is taken from the form of Kalosara which is a symbol of unity and peace from the Tolaki Tribe, as well as from the logo of the Creative Economy Agency. This form is the result of a study of the theme of Expressionism Architecture. The results of the planning of this building are expected to be a reference for the government in creating a place that can support the economy, especially in the creative industry of Kendari City.

Keywords: Creative Center Building, Expressionism Architecture, Kendari City

\section{Abstrak}

Industri ekonomi kreatif saat ini mulai berkembang pesat di beberapa kota di Indonesia, termasuk Kota Kendari. Walaupun tergolong muda, perkembangan ekonomi kreatif di Kota Kendari ditunjang oleh semakin meningkatnya antusias anak muda dalam industri ini. Oleh karena itu, untuk mendukung minat dan bakat masyarakat Kota Kendari khususnya anak muda, penelitian ini bertujuan untuk menciptakan wadah berupa Gedung Pusat Kreativitas dengan tema Expresionisme. Tema ini dipandang sesuai dengan kondisi yang ada di kota ini dimana dapat menggambarkan ekspresi dari pengguna bangunan yang dicerminkan pada tampilan dan interior bangunan. Penelitian ini menggunakan metode Qualitative descriptive serta Quantitatif. Berdasarkan hasil analisis penentuan Lokasi dan tapak, gedung ini direncanakan akan dibangun di Kecamatan Kadia dengan total luas wilayah \pm 4,34 $\mathrm{Ha}$. Tampilan bangunan pada gedung ini diambil dari bentuk Kalosara yang merupakan lambang persatuan dan perdamaian dari Suku Tolaki, serta dari logo Badan Ekonomi Kreatif. Bentuk ini merupakan hasil dari kajian tema Arsitektur Ekspresionisme. Hasil dari perencanaan gedung ini diharapkan dapat menjadi referensi pemerintah dalam menciptakan wadah yang dapat mendukung perekonomian khususnya di bidang Industri Kreatif Kota Kendari.

Kata Kunci: Gedung Pusat Kreatif, Arsitektur Ekspresionisme, Kota Kendari

\section{PENDAHULUAN}

\section{A. Latar Belakang}

Perkembangan

ekonomi kreatif yang berkembang di negara-negara maju kini menyebar ke negara-negara berkembang, salah satunya di Indonesia. Perkembangan yang terjadi menunjukkan sebuah refleksi atas pembangunan yang tidak hanya berlandaskan pada pendapatan ekonomi semata dalam hal ini produksi barang, namun juga meningkatkan pemahaman manusia terhadap budaya kreatif yang didasarkan pada ide, gagasan, dan inovasi.

Sejak munculnya agenda ekonomi kreatif sebagai alternatif industri di tingkat global, ekonomi kreatif pun dengan cepat tumbuh dan berkembang di kota-kota besar dan maju di banyak daerah yang 
ada di Indonesia. Dimana perkembangan perekonomiannya melalui sektor industri.

Kota Kendari yang secara administratif masih tergolong muda terhadap perkembangan ekonomi kreatif namun memiliki cukup banyak generasi yang mempunyai ketertarikan besar terhadap sektor industri kreatif, seperti kreatif desain, kriya, periklanan, radio, fashion, dan seni pertunjukan.

Berdasarkan hasil survey yang telah dilakukan terhadap pelaku ekonomi kreatif di Kota Kendari bahwa apresiasi Pemerintah Kota pada industri kretif masih sangat kurang diperhatikan dikarenakan aktifitas pelaku kreatif selama ini kurang terwadahi dari segi fasilitas, baik fasilitas pelatihan, permodalan, dan ruang pamer. Sehingga untuk mewadahi kegiatan sektor ekonomi kreatif tersebut, perlu adanya Perencanaan Gedung Pusat Kreativitas yang melibatkan komunitas seni guna menghasilkan sebuah karya yang inovasi. Wadah yang akan dihadirkan dapat menunjang kebutuhan pelaku kreatif terkhusus untuk remaja dan anakanak.

Beberapa pandangan masyarakat terhadap pelaku kreatif yaitu memiliki pemikiran secara abstrak maka konsep yang akan diterapkan pada Perencanaan Gedung Pusat Kreativitas di Kendari yaitu Arsitektur Ekspresionisme. Dimana bangunan akan menggambarkan sebuah ekspresi dari pengguna bangunan yang akan dikembangkan dari segi tampilan bangunan dan interiornya. Hal ini secara tidak langsung memberi karakter yang sangat kuat dari bangunan itu sendiri, sehingga mampu menarik bagi penggiat kreativitas untuk memperdalam ilmu di wadah tersebut.

Oleh karena itu, untuk memenuhi kebutuhan minat dan bakat masyarakat Kota Kendari khususnya anak-anak dan remaja dalam hal pengembangan bakat dibidang seni, budaya, desain media, dan komunikasi maka perlu adanya wadah Gedung Pusat Kreativitas di Kota Kendari dengan menerapkan Konsep Arsitektur Ekspresionisme.

\section{B. Pertanyaan Penelitian}

Berdasarkan uraian diatas, maka timbul pertanyaan penelitian:

1. Bagaimana menentukan lokasi yang tepat untuk Perencanaan Gedung Pusat Kreativitas di Kendari?

2. Bagaimana merancang Gedung Pusat Kreativitas di Kendari dengan menerapkan konsep desain Arsitektur Ekspresionisme?

\section{Tujuan dan Sasaran Pembahasan \\ 1. Tujuan Pembahasan \\ a. Menentukan lokasi yang tepat untuk penataan bangunan Gedung Pusat Kreativitas. \\ b. Merancang bangunan Gedung Pusat Kreativitas agar dapat menunjangfungsi bangunan dengan penerapan konsep desain Arsitektur Ekspresionisme. \\ 2. Sasaran Pembahasan}

a. Terwujudnya lokasi yang tepat untuk penatan bangunan Gedung Pusat Kreativitas di Kendari.

b. Terwujudnya rancangan bangunan yang dapat menunjang fungsi bangunan Gedung Pusat Kreativitas dengan penerapan konsep desain Arsitektur Ekspresionisme

\section{Batasan Pembahasan}

Batasan pembahasan perencanaan Gedung Pusat Kreativitas di Kota Kendari dengan menerapkan konsep Arsitektur Ekspresionisme diarahkan pada desain bangunan penggiat seni dan budaya, desain, media dan komunikasi dimana di dalamnya terdapat kegiatan pembelajaran dan fasiltias penunjang.

\section{TINJUAN PUSTAKA}

\section{A. Pengertian Kreativitas}

Menurut Rhodes (dalam Munandar, 2004: 20-22) menjelaskan bahwa terdapat empat istilah dalam kreativitas yaitu "Person, Process, Press, and Product". Dimana penjelasannya sebagai berikut:

a) Person (Pribadi), kreativitas muncul dari keunikan keseluruhan kepribadian dalam interaksi dengan lingkungannya (Hulbeck, dalam Munandar, 2004)

b) Process (Proses), yaitu kreativitas adalah proses yang memanifestasikan diri dalam kelancaran, fleksibilitas, dan orisinalitas pemikiran (Torrance dalam Munandar, 2004).

c) Press (Pendorong) menurut Simpson (1982) dalam S. C. U. Munandar (2004), merujuk pada aspek dorongan internal dengan rumusannya sebagai berikut: "Inisiatif yang diwujudkan oleh kekuatannya untuk melepaskan diri dari urutan pemikiran yang biasa"

d) Product (Produk), yaitu kreativitas adalah kemampuan untuk mewujudkan sesuatu yang baru (Baron, dalam Munandar 2004).

Berdasarkan definisi diatas, kreatif merupakan kemampuan menghasilkan suatu gagasan dengan berbagai macam alternatif dan beberapa proses kreatif yang didukung oleh lingkungan sekitar. Sehingga lingkungan dapat menghargai imajinasi dan fantasi dan menekankan kreativitas serta inovasi.

\section{B. Fungsi dan Tipologi Gedung Pusat Kreativitas}

Pusat Kreativitas adalah tempat yang menyediakan atmosfir untuk anak-anak dan remaja belajar dan mendalamkan ilmu industri kreatif bersama.

1. Fungsi Penujang Gedung Pusat Kreativitas

a) Fungsi Bangunan Pusat Kreatif mempunyai 3 karakteristik kegiatan:

- Apresiatif

Kegiatan memberikan penghargaan, pemahaman, dan penilaian.

- Rekreatif 
Kegiatan bersifat rileks, ringan dan santai untuk menikmati suasana dan karya seni.

- Kreatif

Siswa dan siswi sebagai pelaku dapat menghasilkan sesuatu yang berupa karya seni.

b) Fungsi Bangunan Pusat Kreatif menurut pengguna:

- Tempat menciptakan hasil karya

- Tempat mengumpulkan hasil karya

- Tempat menggelar hasi karya

- Tempat memberikan informasi hasil karya

- Tempat berinteraksi antara pengelar industri kreatif

c) Fungsi bangunan bagi pengunjung:

- Tempat mendapatkan informasi dan pengetahuan tentang industri kreatif

- Tempat peningkatan daya apresiasi industri kreatif

- Tempat berinteraksi dengan para pelaku industri kreatif

- Tepat melakukan kegiatan rekreatif

- Tempat rekreatif dan edukatif

2. Tipologi Gedung Pusat Kreativitas

Gedung Pusat Kreatif masuk dalam tipologi bangunan gedung pendidikan, sekolah informal, museum, pameran dan hiburan. Gedung Pusat Kreatif mempunyai fasilitas untuk kegiatan belajar industri kreatif seperti pentas seni, teknis teater, seni rupa, musik, desain dan arsitektur, kerajinan, tata busana, periklanan, media digital dan perangkat lunak, film, video dan fotografi dan lainlain. Membuat tempat Pusat Kreatif lebih edukatif dan rekreatif, maka tempat akan dilengkapi dengan fasilitas pendukung seperti ruang publik yaitu kafetaria, taman, perpustakaan, musallah, dan pameran tempat pertunjukan auditroium, museum, amphiteater

\section{Tujuan Terhadap Pembangunan Gedung Pusat Kreativitas}

Pendidikan Industri Kreatif sudah mengalami revolusi digital dan globalisasi yang besar dan terbagi menjadi tiga mayor subsektor diantaranya:

1. Seni dan Budaya, adalah mewujudkan pemikiran kreatif dan kritik, yang meliputi analisis budaya visual kontemporer bersama bentuk-bentuk seni, yaitu seni rupa, sastra, musik, teater, film, tari dan lain-lainya.

2. Desain adalah sebuah rencana atau gambar yang menunjukkan tampilan dan fungsi atau kerja bangunan, pakaian, atau benda lain sebelum dibuat.

3. Media dan Komunikasi, adalah penyampain pesan dengan menggunakan alat (media), termasuk media cetak dan video dan lain-lain, dengan maksud memberikan dampak terhadap penerima (komunikan) agar sesuai yang diinginkan oleh komunikator.
Dari tiga mayor subsektor tersebut ada dua belas sektor yang terbagi di masing-masing katagori:

Tabel 1. Tiga Mayor Subsektor Industri Kreatif

\begin{tabular}{|c|c|c|}
\hline Seni dan Budaya & Desain & $\begin{array}{l}\text { Media dan } \\
\text { Komunikasi }\end{array}$ \\
\hline Seni Pertunjukan & Arsitektur & Iklan \\
\hline Teknis Teater & Desain & $\begin{array}{l}\text { Film, Video, } \\
\text { dan } \\
\text { Photography }\end{array}$ \\
\hline Seni Visual & $\begin{array}{l}\text { Kerajinan } \\
\text { Produk }\end{array}$ & $\begin{array}{l}\text { Media, Digital, } \\
\text { dan Perangkat } \\
\text { Lunak }\end{array}$ \\
\hline Musik & Fashion & Siaran \\
\hline
\end{tabular}

(Sumber: Workforce Development Agency, 2015)

\section{Konsep Arsitektur Ekspresionisme}

1) Definisi Arsitektur Ekspresionisme

Penganut paham ekspresionisme memiliki dalil bahwa "Art is anexpression of human feeling" atau seni adalah suatu ungkapan perasaan manusia. Aliran ini terutama bertalian dengan apa yang dialami oleh seseorang seniman ketika menciptakan suatu karya seni. Ekspresionisme merupakan gerakan untuk mencapai campuran cita-cita yang kompleks yang di cirikan sebagai irasional, emosional dan romantik. Aliran ekspresionisme adalah aliran yang ingin mengemukakan segala sesuatu yang bergejolak dalam jiwa. Sifat-sifat yang terkandung dalam karya-karya ekspresionisme adalah adanya unsur subyektivitas yang sangat tinggi.

Ekspresionis adalah kecenderungan seorang seniman untuk mendistorsi kenyataan dengan efekefek emosional. Ekspresionis bisa ditemukan di dalam karya lukisan, sastra, filem, Arsitektur, dan musik. Istilah emosi ini biasanya lebih menuju kepada jenis emosi kemarahan dan depresi daripada emosi bahagia. Ekspresionis juga didefinisikan sebagai kebebasan distorsi bentuk dan warna untuk melahirkan emosi ataupun sensasi dalam perasan manusia yang biasanya dihubungkan dengan kekerasan atau tragedi.

2) Prinsip-prinsip Arsitektur Ekspresionisme Didalam sebuah karya asitektur ekspresionisme, terdapat prinsip-prinsip dalam memahami sebuah desain, yaitu:

- Menghargai kebebasan bentuk dan garis.

- Menghasilkan bentuk bangunan yang tidak monoton (imajinasi seseorang).

- Mengekspresikan bahasa emosi bentuk dan warna.

- Merupakan ungkapan isi hati seseorang.

- Menjelajahi jiwa dan melukiskan emosi kepada orang lain. 
Menurut Erich Mendelsohn dalam penelitiannya menjelaskan bahwa Ekspresionis diuraikan pada kelompok seni dinamik yang di pimpin oleh tiga arsitek, dijelaskan bahwa para kaum simbolis kristalin menempatkan pengalaman simbolik, ideal di atas pengalaman spatial yang nyata, para analis ruang menyadari arsitektur sebagai manifestasi intelektual dari ruang abstrak, dan para analis bentuk berangkat dari persyaratanpersyaratan material yang konstruktif

Demikian maksud dan tujuan dari pada ekspresionis dalam arsitektur adalah untuk menghargai kebebasan berimajinasi dan kebebasan mencipta merupakan seni dalam arsitektur. Kebebasan yang dimaksud ini adalah seni yang tidak hanya dibatasi oleh modul yang akan menjadikan bentuk bangunan terlihat kaku dan monoton. Bentuk ekspresinya biasa terdapat pada emosi kemarahan dan depresi serta emosi bahagia.

\section{METODOLOGI PENELITIAN}

Dalam studi ini metode yang digunakan yaitu deksriptif kualitatif dan kuantitatif. Metode ini menjabarkan secara fakta terhadap informasi yang didapat di lapangan hingga mengarahkan pada hasil berupa kesimpulan (Muhajjin \& Satkiwasari, 2020). Selain itu metode inipun membantu peneliti dalam mencapai tujuan.

\section{HASIL PENELITIAN DAN PEMBAHASAN}

\section{A. Lokasi dan Site Proyek}

1. Nama Proyek : Gedung Pusat Kreativitas

2. Lokasi Proyek : Kecamatan Kadia, Kota Kendari

3. Luas Site : $\pm 4,34 \mathrm{Ha}$

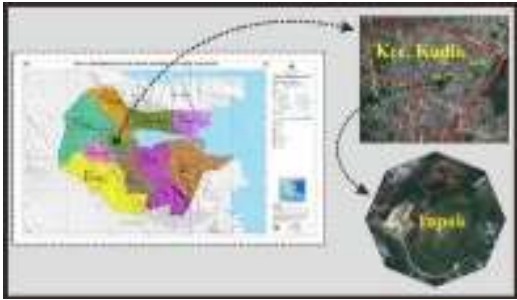

Gambar 1. Lokasi dan Site Perencanaan Gedung Pusat Kreativitas di Kendari

(Sumber: Hasil Analisis Penulis, 2019)

\section{B. Konsep Pengolahan Tapak}

1. Orientasi Matahari

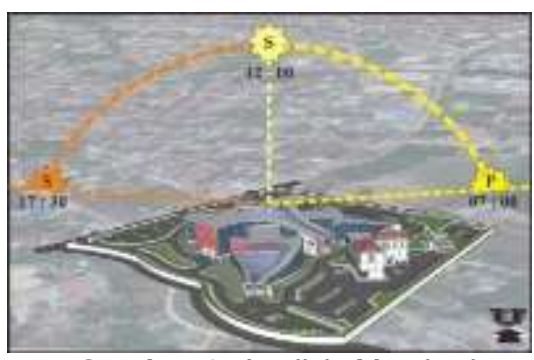

Gambar 2. Analisis Matahari (Sumber: Hasil Analisis Penulis, 2019)

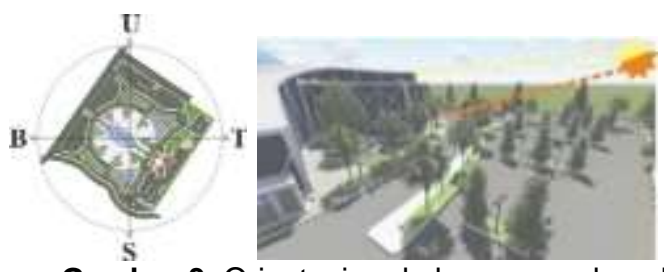

Gambar 3. Orientasi pada bangunan dan elemen pembayang di sekitar bangunan (Sumber: Hasil Analisis Penulis, 2019)

Perencanaan bangunan terhadap optimalisasi panas dari sinar matahari dilakukan dengan cara sebagai berikut:

a. Orientasi bangunan dan bukaan jendela ditempatkan kea rah timur, utara dan selatan.

b. Menyediakan elemen pembayangan

c. Penggunaan material yang tidak tembus cahaya atau dapat menahan cahaya dan permukaan yang transparan

d. Untuk mengatasi kelemahan pencahayaan satu sisi, dapat diciptakan pencahayaan multi sisi bahkan dari sisi atas ruangan agar mengurangi daerah gelap

2. Arah Angin

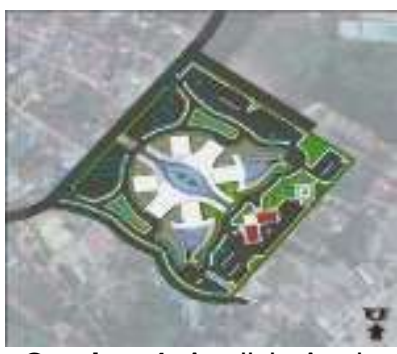

Gambar 4. Analisis Angin

(Sumber: Hasil Analisis Penulis, 2019)
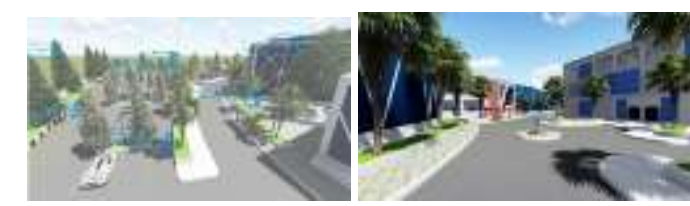

Gambar 5. Penetaan vegetasi terhadap angin dan membuat bukaan pada dinding

(Sumber: Hasil Analisis Penulis, 2019)

Tingkat efisiensi arah angin pada perencanaan ini dilakukan seperti:

a. Membuka bangunan ke arah angin datang

b. Membelokkan angin masuk ke bangunan dengan penghalang pepohonan.

c. Membuat banyak lubang bukaan pada dinding yang berbatasan dengan ruang luar

3. Curah Hujan

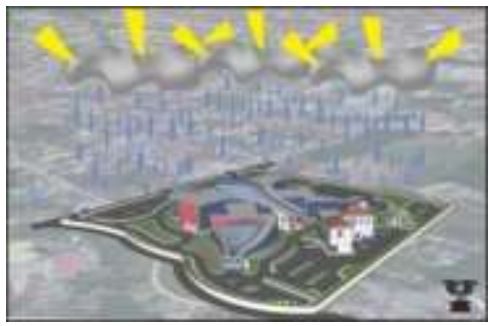

Gambar 6. Analisis Hujan

(Sumber: Hasil Analisis Penulis, 2019) 


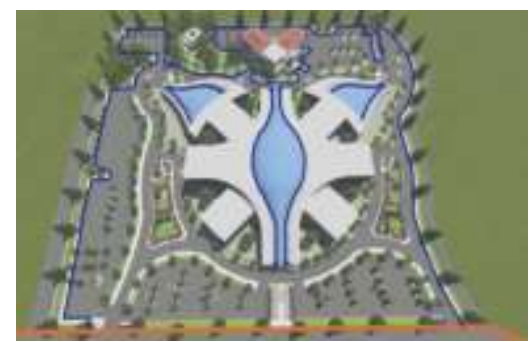

Gambar 7. Penyediaan daerah resapan air pada area tapak, dan lubang-lubang biopori pada bangunan

(Sumber: Hasil Analisis Penulis, 2019)

Intensitas curah hujan yang cukup tinggi, maka perlu adanya perencanaan:

a. Bangunan yang berhubungan dengan kelembaban tanah harus diberi isolasi. Kelembaban kapiler selalu berjalan dari bahan yang berpori besar ke arah bahan yang berpori kecil

b. Kebasahan yang datang dari hujan dapat dilawan oleh lapisan dinding yang berfungsi sebagai perisai air misal dari sirap kayu, aluminium, eternit, plesteran beton rapat air, dengan syarat dinding di belakang lapisan masih bisa bernafas

c. Untuk melindungi dinding terhadap air hujan dari arah atas dan samping dapat dipasang overstek dan tritisan dan dapat dipasang bahan isolasi pada dinding, dengan syarat harus ada lapisan atau celah bebas yang memungkinkan ventilasi pernafasan untuk dinding yang dilindungi maupun untuk bahan isolasi

d. Dapat dipasang dinding rangkap yang tidak saling menghimpit, dinding luar berfungsi sebagai pelindung kebasahan dan sekaligus sebagai isolasi terhadap panas/dingin.

4. Analisis Arah Pandang (View)

Solusi Orientasi View dengan nilai tema terbuka dan jujur, yaitu sebagai berikut:

a. Solusi ke luar

- Memperhatikan tinggi bangunan dengan lingkungan sekitar

- Memaksimalkan pandangan ke luar dengan keterbukaan bangunan maupun layering transparan

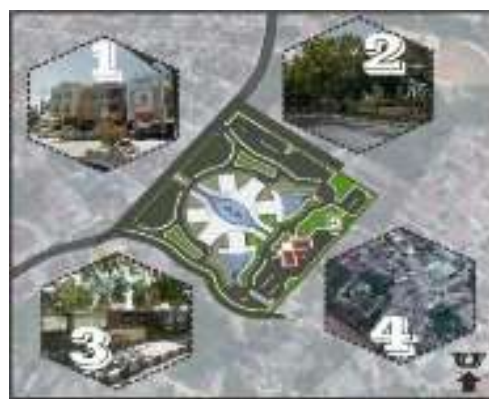

Gambar 8. Analisis Arah Pandang View Ke Luar (Sumber: Hasil Analisis Penulis, 2019) b. Solusi ke dalam

- Menyesuaikan dengan kondisi lingkungan sekitar.

- Menonjolkan bentuk bangunan baru

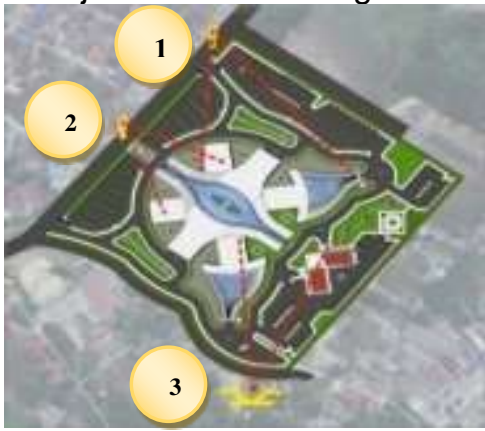

Gambar 9. Analisis Arah Pandang View Ke Dalam (Sumber: Hasil Analisis Penulis, 2019)

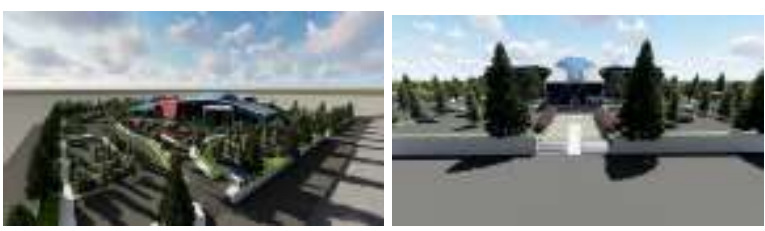

Gambar 10. Lihat dari kiri ke kanan a dari arah masuk kendaraan, b. View dari arah masuk \& kluar pejalan kaki (Sumber: Hasil Analisis Penulis 2019)

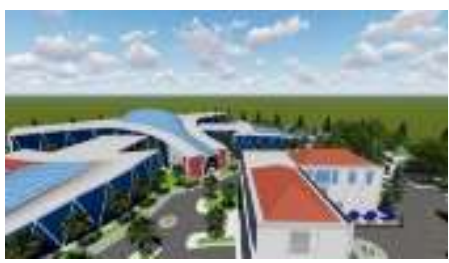

Gambar 11. View dari arah belakang menggunakan drone

(Sumber: Hasil Analisis Penulis, 2019)

5. Analisis Vegetasi

Beberapa vegetasi di lahan eksisting tidak dapat dipertahankan karena mengganggu estetika pada view dan sirkulasi kendaraan.
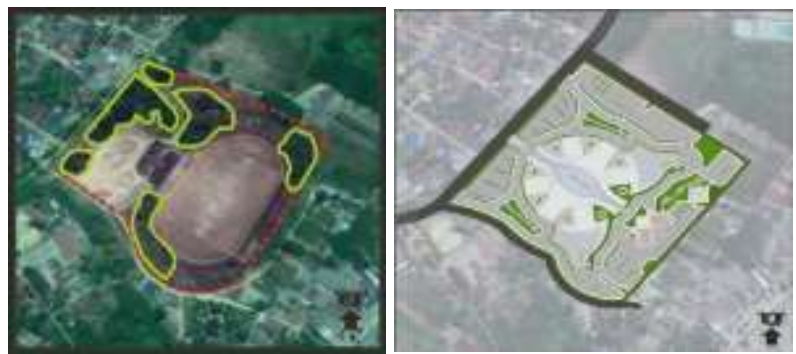

Gambar 12. Perbedaan antara vegetasi yang ada seblum perancangan dan pada saat perancangan (Sumber: Hasil Analisis Penulis, 2019)

6. Analisis Kebisingan

Pemanfaatan vegetasi sebagai filter, pembias dan peredam kebisingan diletakkan pada area jalan utama, entrance tapak dan bangunan, area parkir sampi pada sisi-sisi bangunan 


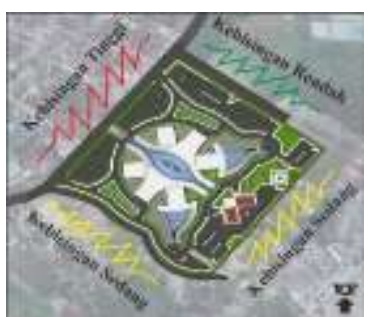

Gambar 13. Analisis Kebisingan (Sumber: Hasil Analisis, Penulis 2019)
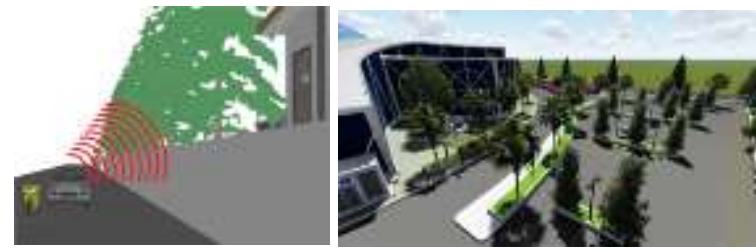

Gambar 14. Pemanfaatan pagar dan vegetasi sebaga peredam kebisingan

(Sumber: Hasil Analisis Penulis, 2019)

\section{Analisis Sirkulasi}

Sirkulasi adalah prasarana penghubung vital yang menghubungkan berbagai kegiatan dan penggunaan dalam sebuah tapak. Pengalaman berbeda-beda saat menelusuri sebuah tapak, dapat diciptakan melalui perubahan-perubahan dalam sistem sirkulasinya.

Sistem sirkulasi menggambarkan seluruh polapola pergerakan kendaraan dan pejalan kaki di dalam dan keluar-masuk tapak. Selain itu, sistem sirkulasi dalam tapak juga menghubungkan tapak tersebut dengan jaringan sistem sirkulasi di luar tapak.

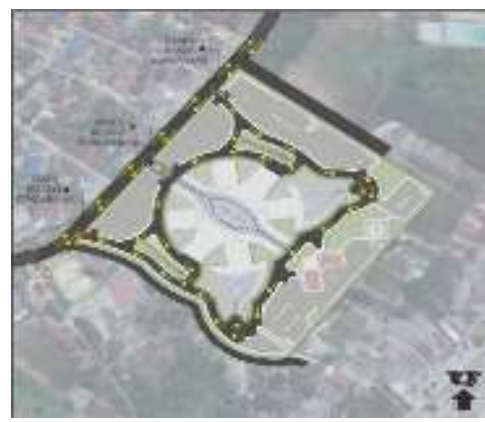

Gambar 15. Analisis Sirkulas

(Sumber: Hasil Analisis Penulis, 2019)

8. Analisis Penzoningan

Penzoningan dilakukan dengan

pengelompokan kegiatan yang sama terhadap kondisi tapak dan kriteria zona penzoningan. Zona Penzoningan terbagi atas:

a. Publik: merupakan zona yang berhubungan secara langsung dengan pengunjung.

b. Semi publik: merupakan peralihan antara zona pengelola dan pengunjung.

c. Servis: merupakan zona yang berhubungan erat dengan kegiatan servis

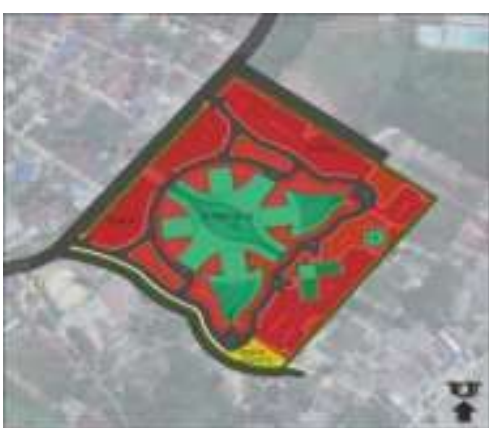

Gambar 16. Zoning Tapak

(Sumber: Hasil Analisis Penulis, 2019)

\section{Konsep Ruang Dalam}

Dalam Perancangan ruang dalam Perlu kita ketahui untuk menghasilkan kenyamanan dalm ruang dalam hal mencapai harmonisasi dan keseimbangan dapat dicapai dengan menerapkan beberapa alemen dasar perancangan ruang dalam, yaitu bidang, cahaya, udara, warna, tekstur, dan akustik.

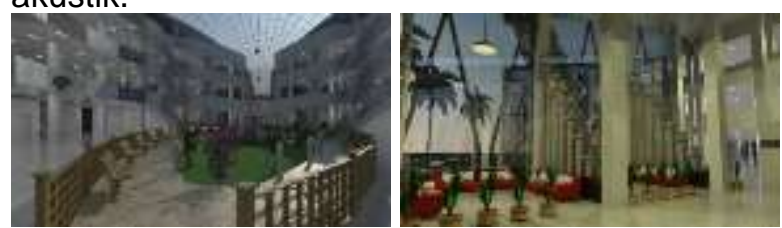

Gambar 17. Dilihat dari kiri ke kanan (a) Atrium, (b) Ruang tunggu

(Sumber: Hasil Analisis Penulis, 2019)

10. Konsep Ruang Luar

Ruang Luar di bedakan menjadi dua, yaitu:

a. Ruang luar aktif adalah rung luar yang digunakan untuk mendukung kegiatan yang ada dalam tapak, yaitu pengadaan sirkulasi, lahan parkir, pelaza, dan pergola

b. Ruang luar pasif adalah ruang luar yang biasnya digunakan sebagai lahan hijau, untuk resapan air, meredam kebisingan, pengara sirkulasi, dan untuk tempat perletakan lampu tamn untuk penarangan tapak.

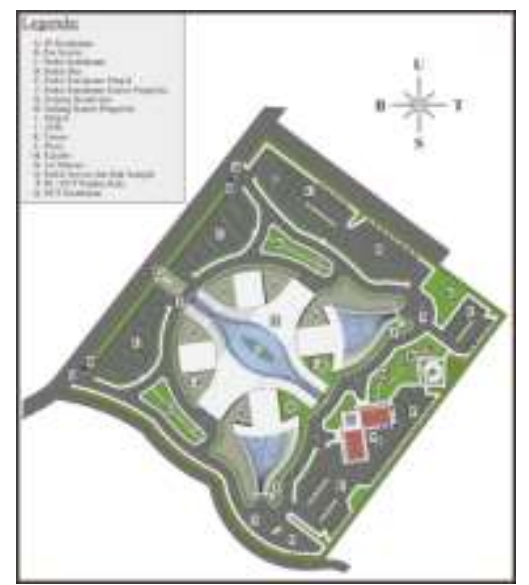

Gambar 18. Blok Plan Tapak

(Sumber: Hasil Analisis Penulis, 2019)

Dalam penataan ruang luar yang perlu diperhatikan adalah penggunaan soft material dan hard material, karena dalam pengolahan landscape pada area Gedung Pusat Kreativitas penggunaan 
bahan soft material dan hard material adalah penentu kenyamanan ruang luar bangunan.

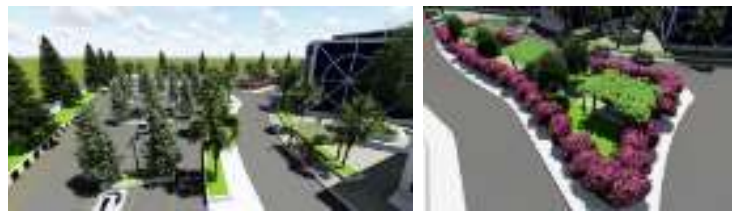

Gambar 19. Soft Material

(Sumber: Hasil Analisis Penulis 2019)

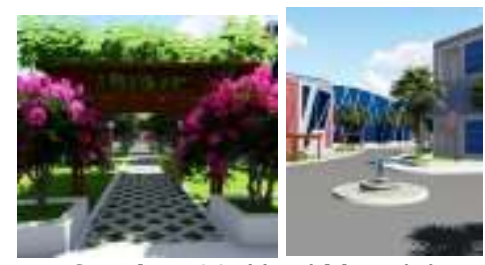

Gambar 20. Hard Material

(Sumber: Hasil Analisis Penulis, 2019)

11. Bentuk dan Tampilan Bangunan

Bangunan ini mengusung konsep arsitektur ekspresionisme dengan mengespresikan logo kalosara lambang pemersatu dan perdamaian yang sangat sakral dalam kehidupan suku tolaki dan logo badan ekonomi kreatif, iya lah lembaga untuk orang - orang kreatif, sehingga pengamat bisa langsung merasakan bahwa bangunan tersebut di peruntukkan untuk pusat kreatifitas di Kota Kendari yang mencirihaskan masyarakat suku tolaki.

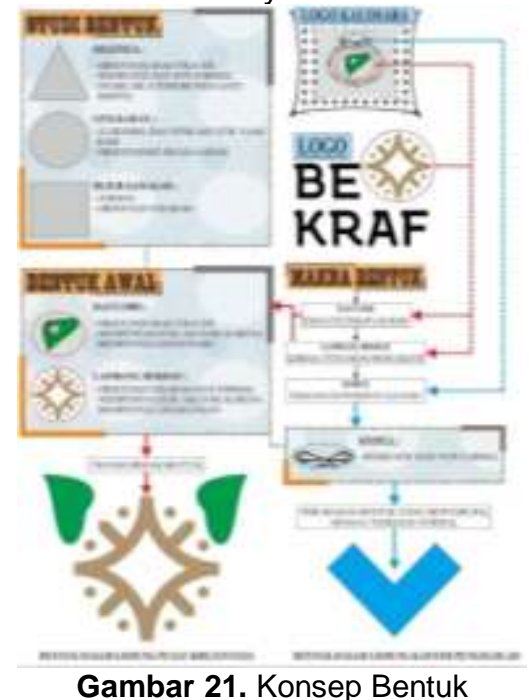

(Sumber: Hasil Analisis Penulis, 2019)

Bentuk bangunan ini memiliki prinsip seni ekspresionisme yang mentransformasikan dua logo dan membentuk sebuah bangunan yang mempunyai makna bentuk bangunan yang bebas, bentuk yang melambangkan logo kalosara merupakan tempat perkumpulan yang akan dijadikan kantor pengelola dan pertunjukan pada perancangan bangunan, sedangkan logo bekraf akan dijadikan suatu tempat untuk mengasah ketangkasan dalam berkreatifitas para pegiat ekonomi kreatif agar dapat bersaing dibidang keterampilan yang dimiliki para pengiat industri kreatif.
12. Tampilan Rancangan

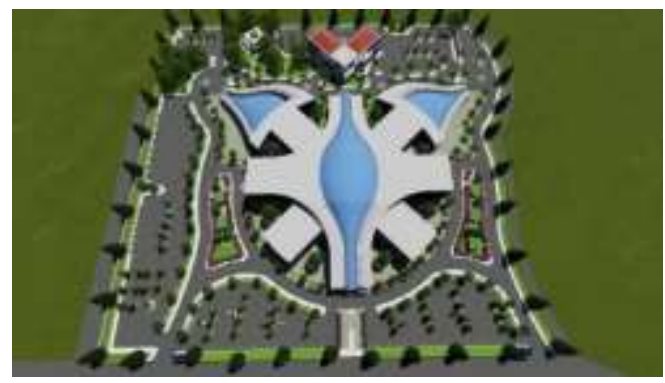

Gambar 22. Tampilan Rancangan (1) Site Plan (Sumber: Hasil Analisis Penulis, 2019)

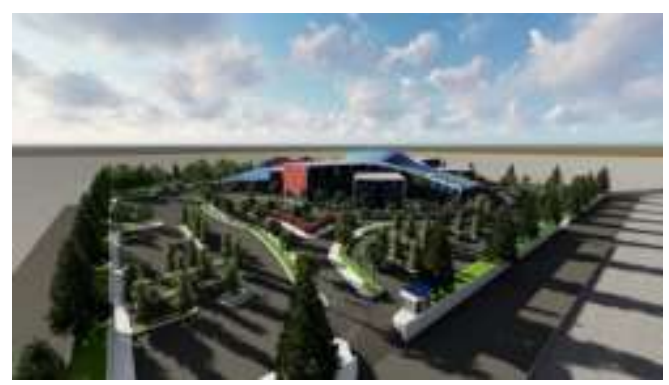

Gambar 23. Tampilan Rancangan (2) (Sumber: Hasil Analisis Penulis, 2019)

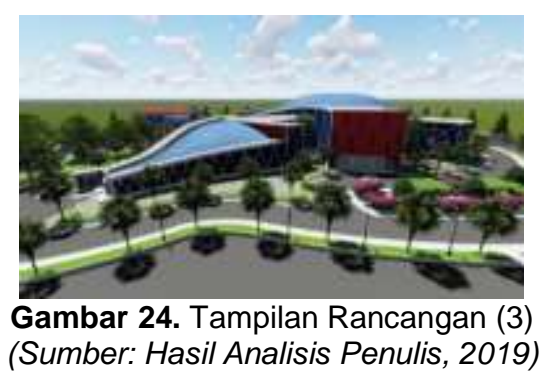

13. Skema Tampilan Bangunan

Tampilan bangunan ini memiliki prinsip seni ekspresionisme, kaca sebagai suatu material memiliki wujud transparan yang memungkinkan manusia untuk meluaskan pandanganya kedalam karakter batasan dan secara ideal mendukung visi akan suatu masyarakat yang terbuka dan bebas.

Ciri dari arsitektur ekspresionisme pada bangunan ini ialah:

a. ACP yang dipasang menyerupai susunan bata merah pada tampilan

b. Distoris bentuk untuk efek emosional

c. Ekspresi simbolik atau gaya dari pengakuan batin.

d. Upaya yang dilakukan adalah untuk tercapainya hasil yang baru, asli, dan visioner

e. Mengunakan potensi kreatif

f. Ekstensif mengunakan beton dan bata

g. Kurangnya simetri

\section{Konsep Besaran Ruang}

Perhitugan besaran ruang agar perancang dapat mengetahui KDB dan KLB yang akan terbangun, maka akan diuraikan sebagi berikut: 


\begin{tabular}{|c|c|c|}
\hline No. & Kelompok Ruang & $\begin{array}{l}\text { Total Luas }(\mathrm{m} 2)+ \\
\text { Sirkulasi }\end{array}$ \\
\hline 1. & $\begin{array}{l}\text { Fasilitas Ruang } \\
\text { luar }\end{array}$ & $\begin{array}{l}3.396,1+60 \% \\
=5.434 \mathrm{~m}^{2}\end{array}$ \\
\hline 2. & Gedung Kreativitas & $\begin{array}{l}13.719,7+30 \% \\
=17.836 \mathrm{~m}^{2}\end{array}$ \\
\hline 3. & $\begin{array}{l}\text { Gedung Pengelola } \\
\text { dan Restaurant }\end{array}$ & $\begin{array}{l}1.410,5+30 \%= \\
1.834 \mathrm{~m}^{2}\end{array}$ \\
\hline 4. & Masjid & $\begin{array}{l}136,7+40 \%= \\
192 \mathrm{~m}^{2}\end{array}$ \\
\hline
\end{tabular}

Perhitungan Luas Lahan Terbangun dan KDH : Koefisien Lantai Bangunan (KLB) :

- Gedung Kreativitas Jumlah Lantai 4 Total $\mathrm{m}^{2}=$ $17.835,6$

- Gedung Kantor Pengelola dan Restauran Jumlah Lantai 3 Total $=1.833,65 \mathrm{~m}^{2}$

Koefisien Dasar Bangunan (KDB) :

- Gedung Kreativitas Lantai $1 /$ Dasar Total = $8.216 \mathrm{~m}^{2}$

- Gedung Kantor Pengelola dan Restaurant Lantai $1 /$ Dasar Total $=611 \mathrm{~m}^{2}$

- Masjid Lantai Total $=192 \mathrm{~m}^{2}$

- Fasilitas Ruang Luar Total $\mathrm{M}^{2}=5.434 \mathrm{~m}^{2}$

Luas KDB + Sirkulasi (\%) $=14.453 \mathrm{~m}^{2}+70 \%$ $=24.570 \mathrm{~m}^{2}$

Luas lahan yang terpilih $=43.400 \mathrm{~m}^{2}-24.570 \mathrm{~m}^{2}$

$$
=18.830 \mathrm{~m}^{2}
$$

Luas Lahan Terbangun $=\frac{24.570 \times 100}{43.400}=56,61 \%$

Luas $\mathrm{KDH}=\frac{18.830 \times 100}{43.400}=43,39 \%$

\section{Konsep Struktur}

Dalam penataan sistem struktur yang perlu diperhatikan adalah penggunaan struktur atap, super struktur dan sub struktur agar mendapatkan sistem struktur yang tepat dan efektif untuk memikul beban yang bekerja serta kondisi tanah yang ada, dan sangup menyesuaikan rancangan bentuk yang diinginkan.

a. Core

Sistem struktur ini berfungsi menahan dan menyalurkan beban gaya horizontal dan vertikal secara merata pada sistem-sistem struktur inti dan struktur pendukung, sehingga bangunan dapat memikul beban horizontal dan vertikal maupun gaya lateral.

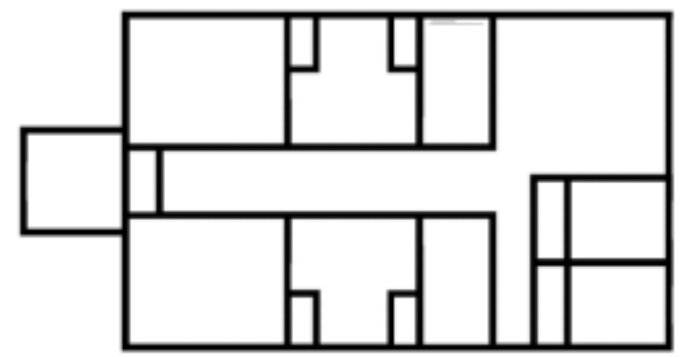

Gambar 25. Struktur Core

(Sumber: Hasil Analisis Penulis, 2019) b. Struktur Atap

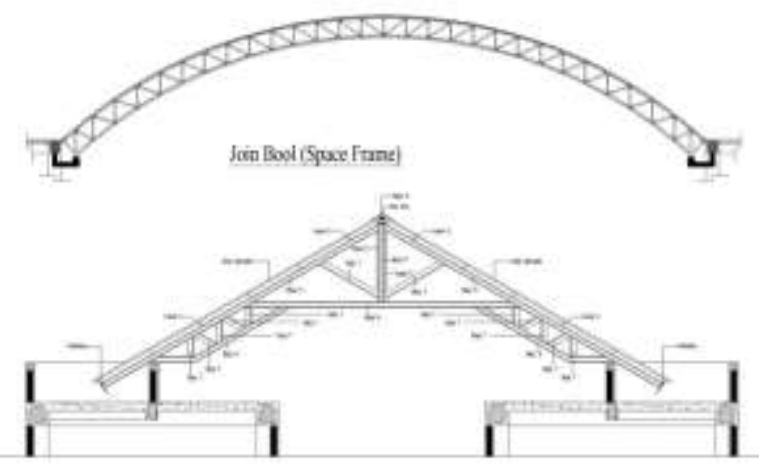

Rangka Baja

Gambar 26. Struktur Rangka Atap Join Ball dan Rangka Baja

(Sumber: Hasil Analisis Penulis 2019)

c. Super Struktur

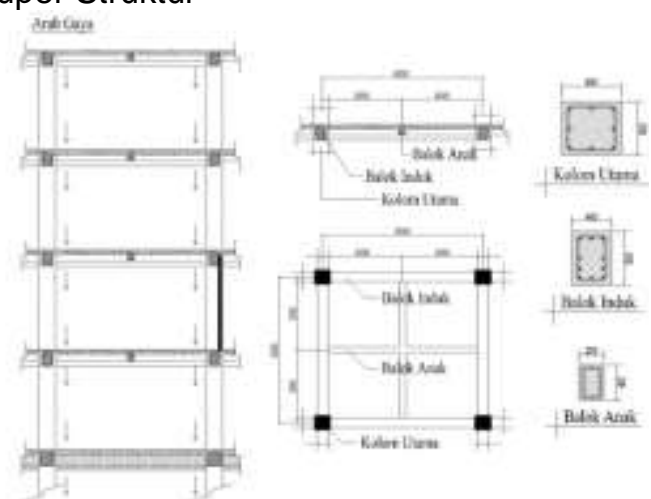

Gambar 27. Super Struktur Balok, Plat,dan Kolom (Sumber: Hasil Analisis Penulis, 2019)

d. Sub Struktur
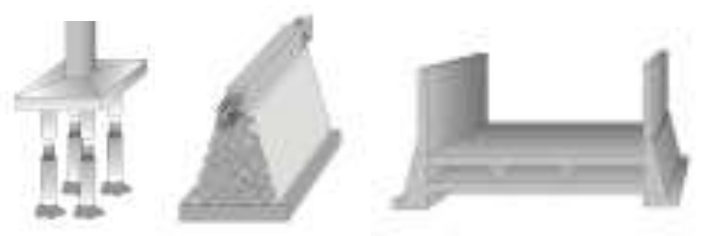

Gambar 28. Sub Struktur Pondasi Pancang, Pondasi Rakit dan Pondasi Garis (Sumber: Hasil Analisis Penulis, 2019)

e. Tampilan Struktur Gedung kreativitas dan Kantor Pengelola

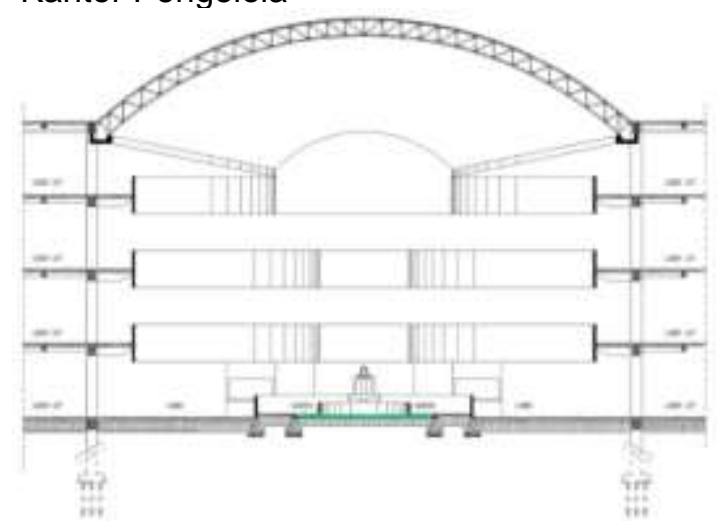

Gambar 29. Out- put Struktur Gedung Kreativitas (Sumber: Hasil Analisis Penulis, 2019) 


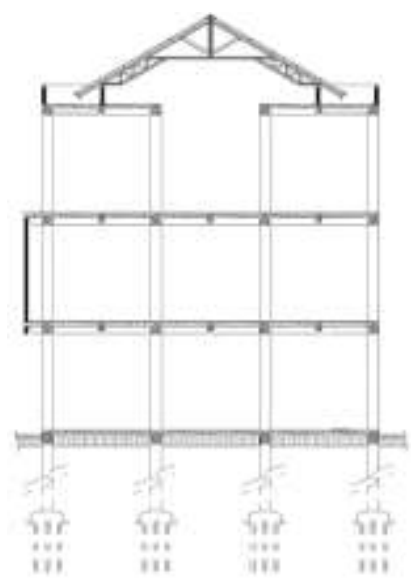

Gambar 30. Out- put Struktur Gedung Kantor Pengelola dan Restauran

(Sumber: Hasil Analisis Penulis, 2019)

16. Konsep Sistem Utilitas

a. Sistem Plumbing dan Sanitasi

- Sistem distribusi air bersih

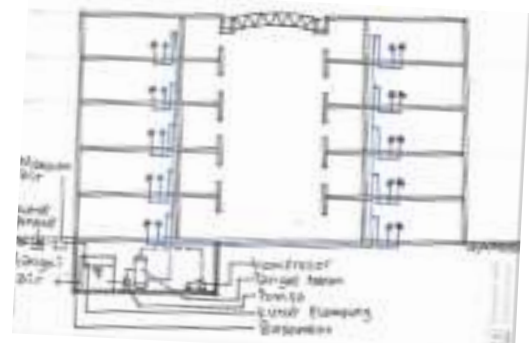

Gambar 31. Sistem Distribusi Air Bersih

(Sumber: Hasil Analisis Penulis, 2019)

- Sistem Pembuangan Air Kotor Padat dan cair

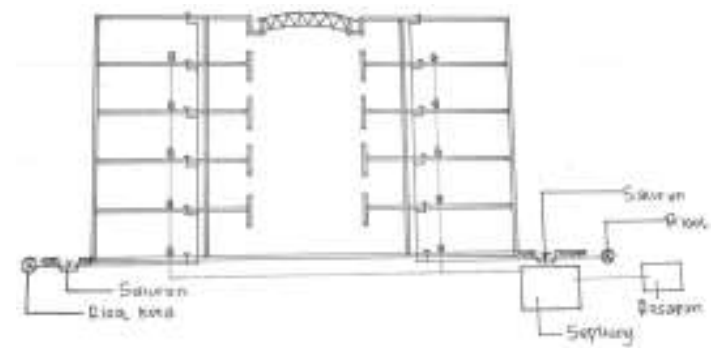

Gambar 32. Sistem Pembuangan Air Kotor padat dan Cair

Sumber: Hasil Analisis Penulis 2019

b. Sistem Pencegah Kebakaran

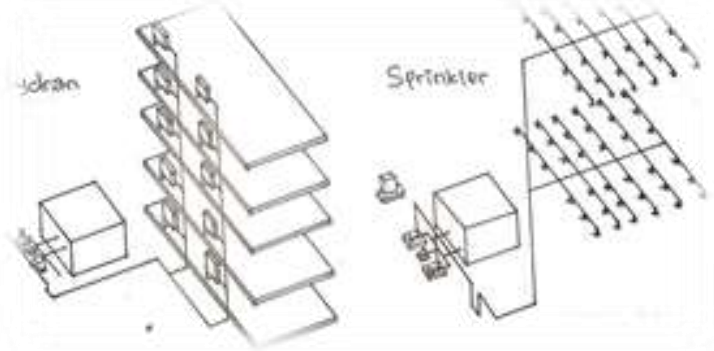

Gambar 33. Sistem Pencegah Kebakaran Sumber: Hasil Analisis Penulis 2019 c. Sistem Transportasi Dalam Bangunan

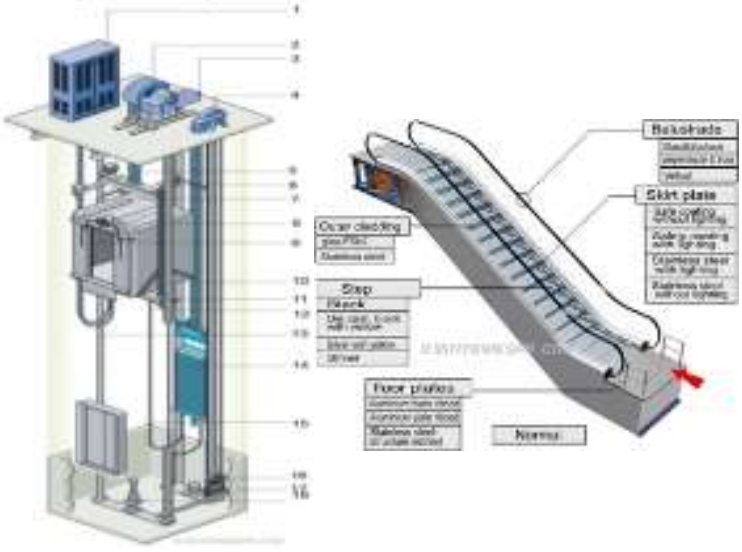

Gambar 39. Sistem Transportasi Dalam Bangunan (Sumber: Hasil Analisis Penulis, 2019)

d. Sistem Persampahan

Penanggulangan masalah sampah dilakukan dengan pengumpulan sampah:

- Penyediaan keranjang sampah pada tempattempat yang mudah diangkut dan dibersihkan.

- Pada area outdoor disediakan bak penampungan sampah yang dibedakan menurut jenisnya (organik dan anorganik)

Kemudian sampah diangkut dari tempat atau keranjang sampah dengan lori ke bak penampungan sampah induk. Selanjutnya sampah diangkut keluar kawasan dengan truk sampah ke tempat pembuangan akhir.

\section{KESIMPULAN}

Gedung Pusat Kreativitas adalah suatu bangunan yang mewadahi bagi para pegiat yang memiliki bakat kreativitas di bidang seni dan desain agar dapat diperlihatkan/dipertunjukkan dan diproduksi melalui media. Dari hasil penelitian dapat di tarik kesimpulan bahwa untuk perancangan Gedung Pusat Kreativitas ada beberapa faktor penentu yang harus di perhatikan yaitu:

1. Potensi lokasi berada pada pusat kota dan berada pada kawasan yang telah ditetapkan dan aksesibilitas untuk mencapai lokasi harus mudah dijangkau kendaraan umum maupun kendaraan pribadi.

2. Tersedianya fasilitas prasarana lain yang mendukung seperti jaringan air bersih, jaringan listrik, jaringan telefon, maupun pemadam kebakaran.

3. Terwujudnya penerapan Arsitektur Expresionisme kedalam desain sehingga pengamat bisa merasakan bahwa bangunan tersebut berfungsi sebagai Gedung Pusat Kreativitas.

\section{DAFTAR PUSTAKA}

Antariksa, B. (2010). Konsep "Indonesia Kreatif" Tinjauan Awal Mengenai Peluang Dan Tantangannya Bagi Pembangunan Indonesia. 
Ariestadi, D. (2008). Teknik Struktur Bangunan Jilid 2.

Bambang Hadibroto, S. M. (2016). Aspek Perancangan Kenikmatan Fisik Bangunan Terhadap Pengaruh Iklim.

Ching, F. D. (2008). Arsitektur Bentuk, Ruang, dan Tatanan Edisi ketiga.

Erdiono, M. D. (2012). Implementasi Aliran Seni Ekspresionisme Dalam Karya Arsitektur.

Hardani, W. (2002). Ernst Neufert Data Arsitek, Edisi 33, Jilid II.

Indarto, P. W. (1996). Ernst Neufert Data Arsitek, Edisi 33, Jilid I.

Joseph De Chiara, J. P. (1992). Time - Saver Standards for Interior Design and Space Planning.

Juwana, J. S. (2000). Panduan Sistem Bangunan Tinggi, Untuk Arsitek dan Praktisi Bangunan. Jakarta.

Laksito, B. (2012). Metode Perencanaan dan Perancangan Arsitektur.

Muhajjalin, M., \& Satwikasari , A. (2020). Kajian Penerapan Konsep Arsitektur Hijau Pada Bangunan Museum Geologi Studi Kasus : Museum Fossa Magna Jepang. Jurnal Arsitektur PURWARUPA , 04 (1), 26.

Munandar, Utami. 2004. Mengembangkan Bakat dan Kreatifitas Anak Sekolah: Jakarta: Gramedia.

Shiba, A. (2016). Analisis Lokasi dan Keruangan.

Siswanto, J. M. (2011). Penerapan Prinsip Prinsip Seni Ekspresionisme Dalam Rancangan Arsitektur .

Suparman, V. W. (1999). Tata Ruang Luar 01.

Tisnawati, A. A. (2014). Sejarah Konsep Tata Cahaya, Warna, Tekstur dan Pola Standardisasi Istilah Interior ( Teori Interior).

Zuhri, S. (2011). Sistim Struktur Pada Bangunan Bertingkat. 